Article

\title{
Physicochemical and Biological Properties of Gelatin Extracted from Marine Snail Rapana venosa
}

\author{
Alexandra Gaspar-Pintiliescu ${ }^{1}$, Laura Mihaela Stefan ${ }^{1, *}$, Elena Daniela Anton ${ }^{1}$, \\ Daniela Berger $^{2}$ (D), Cristian Matei ${ }^{2} \mathbb{D}$, Ticuta Negreanu-Pirjol ${ }^{3}$ and Lucia Moldovan ${ }^{1}$ \\ 1 Departament of Cellular and Molecular Biology, National Institute of R\&D for Biological Sciences, \\ 296 Splaiul Independentei, 060031 Bucharest, Romania; alex.gaspar@yahoo.com (A.G.-P.); \\ danielaanton89@gmail.com (E.D.A.); moldovanlc@yahoo.com (L.M.) \\ 2 Faculty of Applied Chemistry and Material Science, University "Politehnica" of Bucharest, 1-7 Gheorghe \\ Polizu street, 011061 Bucharest, Romania; danaberger01@yahoo.com (D.B.); cristi_matei@yahoo.com (C.M.) \\ 3 Faculty of Pharmacy, University “Ovidius” of Constanta, 1 Aleea Universitatii, 900470 Constanta, Romania; \\ ticuta_np@yahoo.com \\ * Correspondence: lauramihaelastefan@yahoo.com; Tel./Fax: +40-21-2200882
}

Received: 26 July 2019; Accepted: 15 October 2019; Published: 17 October 2019

\begin{abstract}
In this study, we aimed to obtain gelatin from the marine snail Rapana venosa using acidic and enzymatic extraction methods and to characterize these natural products for cosmetic and pharmaceutical applications. Marine gelatins presented protein values and hydroxyproline content similar to those of commercial mammalian gelatin, but with higher melting temperatures. Their electrophoretic profile and Fourier transform infrared (FTIR) spectra revealed protein and absorption bands situated in the amide region, specific for gelatin molecule. Scanning electron microscopy (SEM) analysis showed significant differences in the structure of the lyophilized samples, depending on the type of gelatin. In vitro studies performed on human keratinocytes showed no cytotoxic effect of acid-extracted gelatin at all tested concentrations and moderate cytotoxicity of enzymatic extracted gelatin at concentrations higher than $0.5 \mathrm{mg} / \mathrm{mL}$. Also, both marine gelatins favored keratinocyte cell adhesion. No irritant potential was recorded as the level of IL- $1 \alpha$ and IL-6 proinflammatory cytokines released by $\mathrm{HaCaT}$ cells cultivated in the presence of marine gelatins was significantly reduced. Together, these data suggest that marine snails are an alternative source of gelatins with potential use in pharmaceutical and skincare products.
\end{abstract}

Keywords: gelatin; marine gastropod; Black Sea; acidic and enzymatic extraction; biocompatibility; cytokines

\section{Introduction}

Gelatin is a protein obtained by thermal denaturation of collagen, the main constituent of connective tissue. Being a derivate product of collagen, gelatin has similar structural features and properties [1]. The primary structure of collagen type I consists of two $\alpha 1$-chains and one $\alpha 2$-chain containing the repeating amino acid sequence Gly-X-Y, where $X$ and $Y$ are mainly proline and hydroxyproline [2]. The specific primary structure leads to left-handed helices (secondary structure) and three alpha chains organize into a right-handed triple helix, forming a collagen molecule of $300 \mathrm{~nm}$ in length and less than $2 \mathrm{~nm}$ in diameter [3]. The denaturation process of collagen implies partial destruction of its tertiary, secondary and, to some extent, its primary structure, resulting in gelatin as a mixture of proteins and polypeptides [4].

Gelatin is extensively used as a natural biomaterial in tissue engineering due to its high biocompatibility, biodegradability, low antigenicity, and ability to stimulate cellular attachment 
and growth [5]. So far, commercial gelatin is conventionally obtained from mammalian tissues, like skin and bones from bovine, porcine, or caprine species. Recently, there has been great interest in obtaining gelatin from other sources, especially marine organisms, in order to avoid transmitting bovine spongiform encephalopathy or swine flu, as well as for religious reasons [6]. Moreover, byproducts of different fish species $[7,8]$ and other marine sources have been used for gelatin extraction, such as sponges [9-11], jellyfishes [12,13], squids [14,15], or snails [16,17].

Rapana venosa is a marine snail belonging to the Muricidae family that is rich in proteins, amino acids, sterols, and vitamins [18-20]. It is a predatory marine snail that quickly expanded in the Black Sea, having a negative effect on the ecosystem, especially inducing the decline of different species of mussels and mollusks [21]. Besides its nutritional value [18,22], R. venosa is also appreciated as a potential source for biotechnological applications. Previous studies have reported that amino acids and lipids extracted from $R$. venosa exhibited wound-healing properties on rat skin burns [18,23]. Recently, Luo et al. [24] obtained protein hydrolysates from $R$. venosa with significant antioxidant activity.

The aim of this study was to extract and characterize gelatin from the soft tissue of $R$. venosa using acidic and enzymatic methods, in order to assess their use in the pharmaceutical and cosmetic fields. Its physicochemical and ultrastructural properties were analyzed and compared to those of commercial pig skin gelatin. In addition, marine gelatins were tested on human keratinocyte cells for their cytocompatibility, cell adhesion capacity, and irritant potential.

\section{Results and Discussion}

\subsection{Physicochemical and Structural Properties of Marine Gelatins}

\subsubsection{Yield Extraction and Gelatin Characteristics}

In order to obtain gelatin, insoluble native collagen is subjected to thermal hydrolysis, using chemical and enzymatic methods. Both methods are intended to break the inter- and intramolecular crosslinks without cleavage of the peptide bonds, so that the polypeptide chains remain intact [25]. In our study, after the pretreatment of the marine snail soft tissue with $\mathrm{NaOH}$, chemical hydrolysis was performed using acetic acid, an organic acid capable to induce higher solubility of the tissue during the extraction process [25], resulting in an acid-solubilized gelatin (ASG) solution. The pepsin-solubilized gelatin (PSG) solution was obtained by enzymatic hydrolysis with pepsin, which cleaves bonds in the telopeptide region of the collagen structure [26]. Applying these two methods at $60^{\circ} \mathrm{C}$, we have obtained a higher extraction yield for the acidic treatment $(9.71 \%)$, compared to the enzymatic one $(8.65 \%)$ (Table 1).

Table 1. Yield and characteristics of acid-solubilized gelatin (ASG) and pepsin-solubilized gelatin (PSG) from $R$. venosa and commercial pig skin gelatin (CG). The results are expressed as mean $\pm \mathrm{SD}(n=3)$. * $p<0.05$, compared to CG sample.

\begin{tabular}{ccccc}
\hline $\begin{array}{c}\text { Gelatin } \\
\text { Type }\end{array}$ & $\begin{array}{c}\text { Extraction Yield } \\
\mathbf{( \% )}\end{array}$ & $\begin{array}{c}\text { Protein Content } \\
\mathbf{( \% )}\end{array}$ & Hyp Content (\%) & $\begin{array}{c}\text { Melting } \\
\text { Temperature }\left({ }^{\circ} \mathbf{C}\right)\end{array}$ \\
\hline ASG & $9.71 \pm 0.38$ & $91.48 \pm 4.61$ & $10.62 \pm 0.37$ & $35.30 \pm 1.56$ \\
PSG & $8.65 \pm 0.42$ & $83.12 \pm 3.30$ & $9.39 \pm 0.51 *$ & $33.20 \pm 1.38$ \\
CG & - & $86.12 \pm 3.23$ & $11.17 \pm 0.21$ & $28.80 \pm 1.93$ \\
\hline
\end{tabular}

The yield values were comparable to those of gelatin extracted from squids $(7.5 \%)$, but were lower than those obtained from jellyfish (11.8\%-12\%) and several fish species (ranging between $11.3 \%$ and $20.27 \%$ ) $[14,27,28]$. A previous study reported a yield of $8.69 \%, 10.57 \%$, and $6.54 \%$ of gelatin extracted from the body, foot, and viscera of Ficus variegata gastropod [16]. The gelatin extraction yields are affected by the tissue used for extraction, the quantity of soluble components in the source, or the collagen content [17]. According to Jamilah and Harvinder [29], the yield extraction can also be influenced by other factors, such as temperature, time of extraction, concentration of $\mathrm{NaOH}$ or acetic 
acid, tissue/enzyme ratio, and $\mathrm{pH}$. The temperatures ranging between 45 and $60{ }^{\circ} \mathrm{C}$ are considered optimal regarding the extraction yield of gelatin [30,31]. Higher temperature and longer time of extraction could result in an increased yield, but loss of functional properties of gelatin [30].

The protein content of both marine gelatins was high (91.48\% for ASG and $83.12 \%$ for PSG) and comparable to that of the commercial pig skin gelatin (CG), indicating the efficiency of the used extraction methods (Table 1).

ASG and CG samples showed similar Hyp values (10.62\% and $11.17 \%$, respectively), while PSG exhibited a slightly lower Hyp content (9.39\%). Glycine, proline, and hydroxyproline are the most abundant amino acids found in variable amounts in gelatin compositions depending on the source. The total amount of proline and hydroxyproline in fish gelatin is about $16 \%-20 \%$ [32]. Our data were comparable to those reported for gelatin extracted from ribbon jellyfish (Chrysaora sp.) and tilapia fish skin, with a Hyp content of $8.2 \%$ and $10.31 \%$, respectively [33,34].

The melting temperature, determined by differential scanning calorimetry, was higher for ASG and PSG samples (35.3 and $33.2^{\circ} \mathrm{C}$, respectively) compared to CG $\left(28.8^{\circ} \mathrm{C}\right)$ (Table 1 , Supplementary Figure S1). However, the melting temperature values of ASG and PSG extracted from $R$. venosa were close to those reported for gelatin derived from other marine sources, such as Chondrosia reniformis $\left(30.48{ }^{\circ} \mathrm{C}\right)$ and Thymosia guernei $\left(31.02{ }^{\circ} \mathrm{C}\right)$ marine sponges [35]. In our study, the gelatin samples obtained from the marine snail $R$. venosa showed thermal stability, indicating the possibility of using these components for the development of new biomaterials that require heat resistance.

\subsubsection{SDS-Polyacrylamide Gel Electrophoresis (SDS-PAGE)}

Figure 1 shows the marine gelatins from $R$. venosa evaluated by electrophoresis in polyacrylamide gel and compared to that of CG from pig skin.

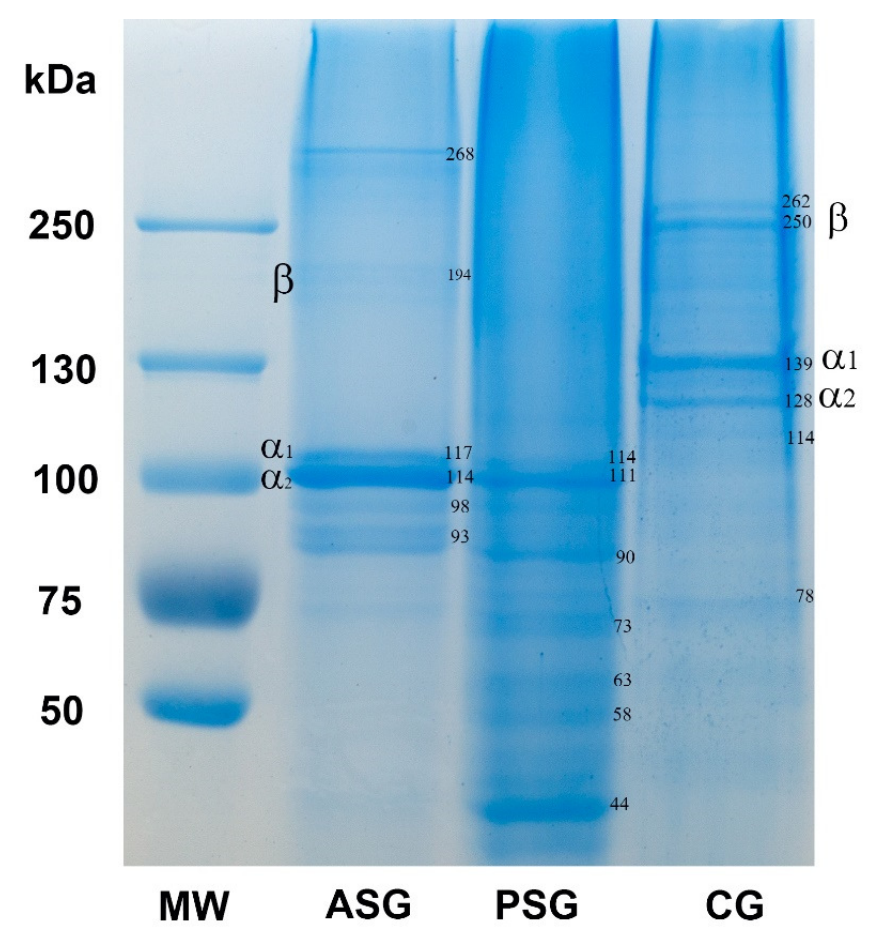

Figure 1. SDS-polyacrylamide gel electrophoresis (SDS-PAGE) showing ASG and PSG marine gelatins from $R$. venosa and CG from pig skin; MW-molecular weight marker. Numbers represent the molecular weight of different protein bands identified in marine and commercial gelatins.

The ASG sample presented $\alpha$ - and $\beta$-chains, as major protein constituents, corresponding to the following molecular weights: $\sim 114-117$ and $\sim 194 \mathrm{kDa}$, respectively. For ASG, a higher molecular weight protein of $\sim 268 \mathrm{kDa}$ and two lower molecular weight proteins of $\sim 93-98 \mathrm{kDa}$ were also observed. 
The presence of $\beta$-dimer and the protein of $\sim 268 \mathrm{kDa}$ indicated that ASG contains intermolecular crosslinks which have not been hydrolyzed during the extraction. The electrophoretic pattern of ASG was similar with those reported for gelatin extracted from marine snails Hexaplex trunculus and Ficus variegate $[16,17]$. The PSG did not display $\beta$-chains, but revealed the presence of $\alpha$-chains at $~ 111-114$ $\mathrm{kDa}$ and several protein bands with low molecular mass of $\sim 90,73,63,58$, and $44 \mathrm{kDa}$. This mixture of polypeptides is probably the result of a high degree of hydrolysis due to the pepsin treatment for $24 \mathrm{~h}$ and the additional heat treatment at $98^{\circ} \mathrm{C}$. Previous studies showed that gelatin extracted from shark skin and African catfish exhibited an increase in shorter chain fragments and a decrease in the intensity of high molecular weight chains, findings which were consistent with our results [36,37]. Both gelatin samples obtained in this study exhibited bands corresponding to $\alpha$-chains with a lower molecular mass ( 110-117 kDa) than that of CG (123-139 kDa). The CG presented the typical $\alpha-(\sim 123-139 \mathrm{kDa})$ and $\beta$-chains $(\sim 250-262 \mathrm{kDa})$ corresponding to collagen type I and several bands of polypeptides with molecular weight of 114 and $78 \mathrm{kDa}$. Similar results were reported for collagen extracted from different fish species, which consisted of two $\alpha_{1}$ and one $\alpha_{2}$ chains with slightly lower molecular weight than collagen type I from calf skin [38]. Collagen from small-spotted catshark also exhibited $\alpha$ subunits lower than $110 \mathrm{kDa}$ [39]. The differences in the $\alpha$ - and $\beta$-chains position between species is probably related to the number of amino acids, which differ between marine and mammalian collagens [7].

\subsubsection{Fourier Transform Infrared (FTIR) Spectroscopy}

In order to study the secondary structure of gelatin samples isolated from marine snail, we have used FTIR spectroscopy analysis. The FTIR spectra of the tested samples are shown in Figure 2.

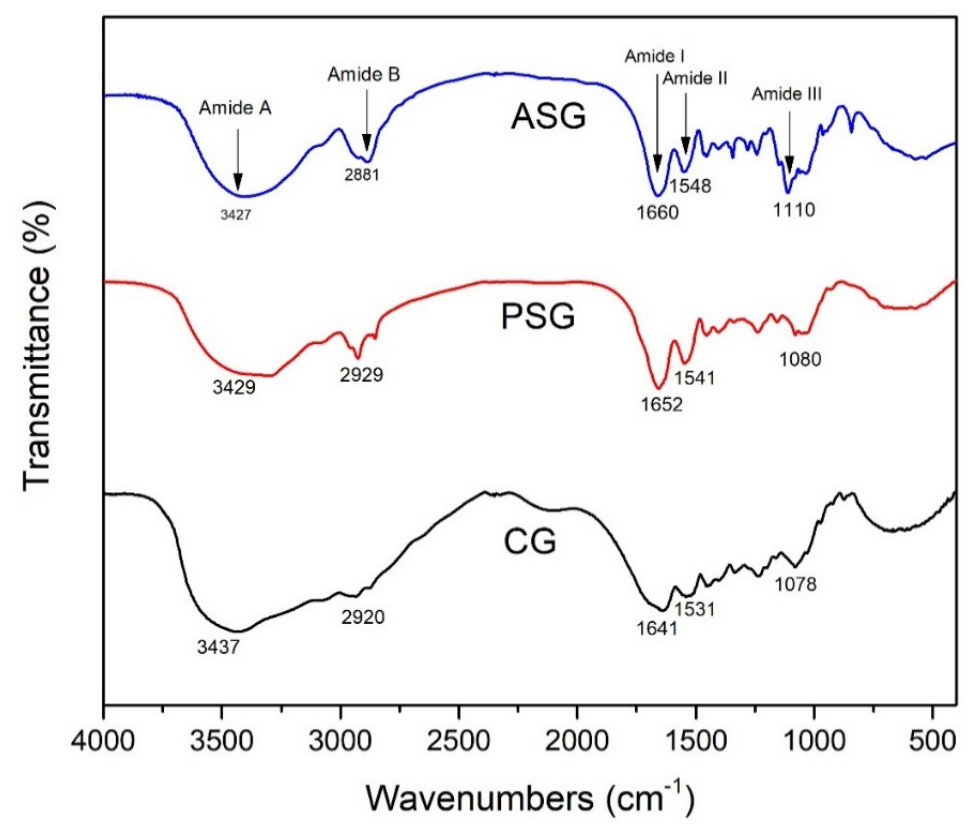

Figure 2. Fourier transform infrared (FTIR) spectra of ASG and PSG marine gelatins from $R$. venosa compared to CG from pig skin.

R. venosa gelatins exhibited main absorption bands, specific for the peptide bonds in the amide band regions. Thus, the amide A large band, associated with $\mathrm{N}-\mathrm{H}$ stretching vibration, depending on the conformation of gelatin, shifted to lower wavenumbers for ASG $\left(3427 \mathrm{~cm}^{-1}\right)$ and PSG $\left(3429 \mathrm{~cm}^{-1}\right)$ samples compared to CG $\left(3437 \mathrm{~cm}^{-1}\right)$, which demonstrated a lower structural order of polypeptide chains. The amide $\mathrm{B}$ bands, corresponding to symmetric and asymmetric vibrations of $\mathrm{C}-\mathrm{H}$ bonds, were observed at $2881 \mathrm{~cm}^{-1}$ for ASG. The amide I band corresponding to the $\mathrm{C}=\mathrm{O}$ stretching vibration from amide group shifted towards higher wavenumbers, at 1660 and $1652 \mathrm{~cm}^{-1}$ for ASG and PSG, respectively, when compared to CG $\left(1641 \mathrm{~cm}^{-1}\right)$, due to the weaker H-bond formation in snail gelatins. 
The amide II band resulted from the overlap of amide $\mathrm{N}-\mathrm{H}$ bending and $\mathrm{C}-\mathrm{N}$ stretching vibrations appeared at $1548 \mathrm{~cm}^{-1}$ for ASG sample and shifted at $1541 \mathrm{~cm}^{-1}$ for PSG sample, probably as a result of higher content of imide bonds formation. The amide II band of CG from $1531 \mathrm{~cm}^{-1}$ was larger and shifted towards lower wavenumbers than that of marine gelatins, which was consistent with a more disordered helical structure with more imide bonds formation. In the FTIR spectra, the amide III band was assigned to $\mathrm{NH}$ bending at $1230 \mathrm{~cm}^{-1}$, while $\mathrm{C}-\mathrm{O}$ stretching vibrations superimposed with $\mathrm{C}-\mathrm{N}$ stretching vibrations were identified at 1110, 1080, and $1078 \mathrm{~cm}^{-1}$ for ASG, PSG and CG, respectively, suggesting a degree of glycosylation [40].

Overall, these results indicated a comparable structure and chemical composition of the gelatins obtained from $R$. venosa using acidic or enzymatic extraction, but a structure less associated by hydrogen bonding in the case of ASG. In addition, slight differences between marine and pig skin gelatins were observed probably due to variations in the sequence of amino acids. Similar FTIR spectra were reported for collagen/gelatin extracted from C. reniformis marine sponge [10].

\subsubsection{Scanning Electron Microscopy (SEM) Observations}

The ultrastructure of the obtained samples was observed by SEM. The lyophilized samples of ASG exhibited a rough, multilayered appearance, in contrast to PSG and CG samples, which showed a fibril-like network forming a microporous structure with uneven sized pores (Figure 3). A previous study has reported a nonfibrillar form of collagen/gelatin extract obtained from C. reniformis marine sponge, which presented a nodular structure with a rough appearance [10].
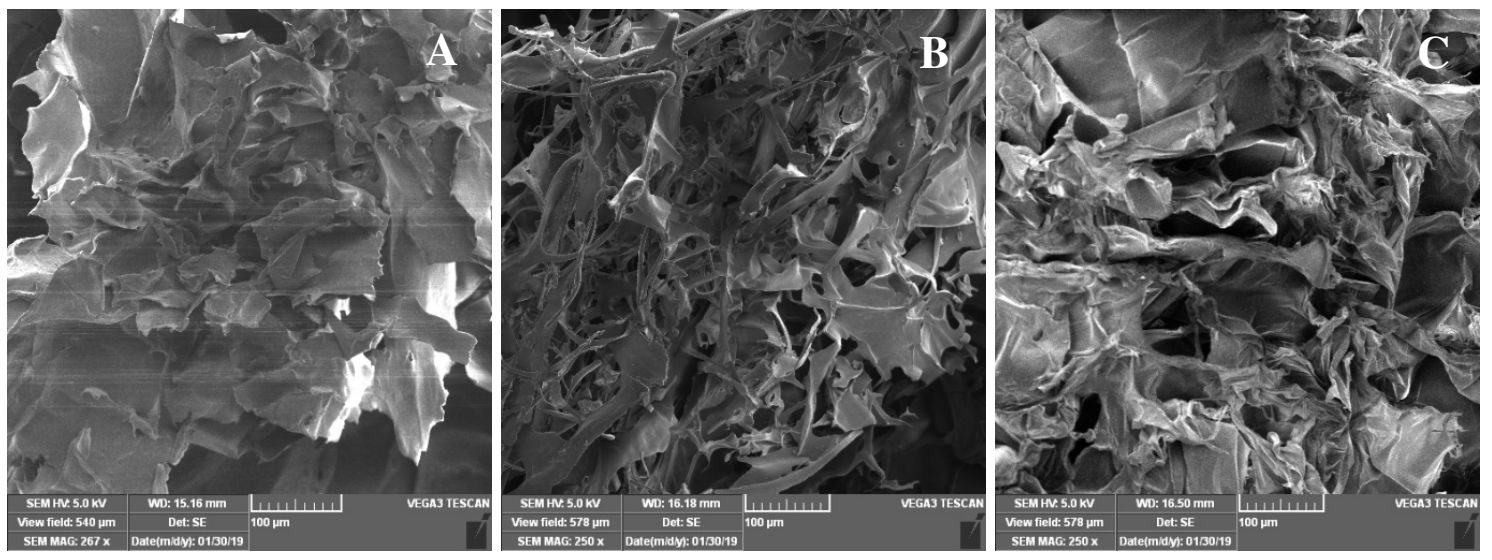

Figure 3. Scanning electron micrographs showing the surface of freeze-dried (A) ASG and (B) PSG from $R$. venosa and (C) CG from pig skin.

\subsection{In Vitro Biocompatibility of Marine Gelatins}

\subsubsection{Evaluation of Cell Viability}

The percentage of cell viability after the treatment with different concentrations of ASG, PSG, and CG was assessed by MTT assay, which evaluates the activity of mitochondrial dehydrogenases. ASG sample showed a good biocompatibility at all tested concentrations $(0.05-1.5 \mathrm{mg} / \mathrm{mL})$ and at both exposure times (24 and $48 \mathrm{~h}$ ) (Figure 4). All cell viability values were above $80 \%$ (noncytotoxic effect), ranging between $90.49 \%$ and $97.59 \%$ after $24 \mathrm{~h}$ of treatment, and between $80.05 \%$ and $97.47 \%$ after $48 \mathrm{~h}$. On the other hand, PSG sample showed no cytotoxic activity at all tested concentrations after $24 \mathrm{~h}$ of exposure (viability values between $82.55 \%$ and $98.68 \%$ ), whereas CG exhibited viability values above $80 \%$ only within the concentration range of $0.05-0.5 \mathrm{mg} / \mathrm{mL}$. After $48 \mathrm{~h}$, PSG maintained a good biocompatibility up to the concentration of $0.5 \mathrm{mg} / \mathrm{mL}$ (viability values between $81.93 \%$ and $96.63 \%$ ), but cell viability decreased below $75 \%$ at higher concentrations. The CG sample showed a similar profile with that observed after $24 \mathrm{~h}$ of treatment, with viability values below $80 \%$ at concentrations 
higher than $0.5 \mathrm{mg} / \mathrm{mL}$. Overall, the ASG exhibited no cytotoxic effect at all tested concentrations, whereas the PSG and CG showed a similar biocompatibility, with cell viability values decreasing below $80 \%$ at concentrations higher than $0.5 \mathrm{mg} / \mathrm{mL}$.

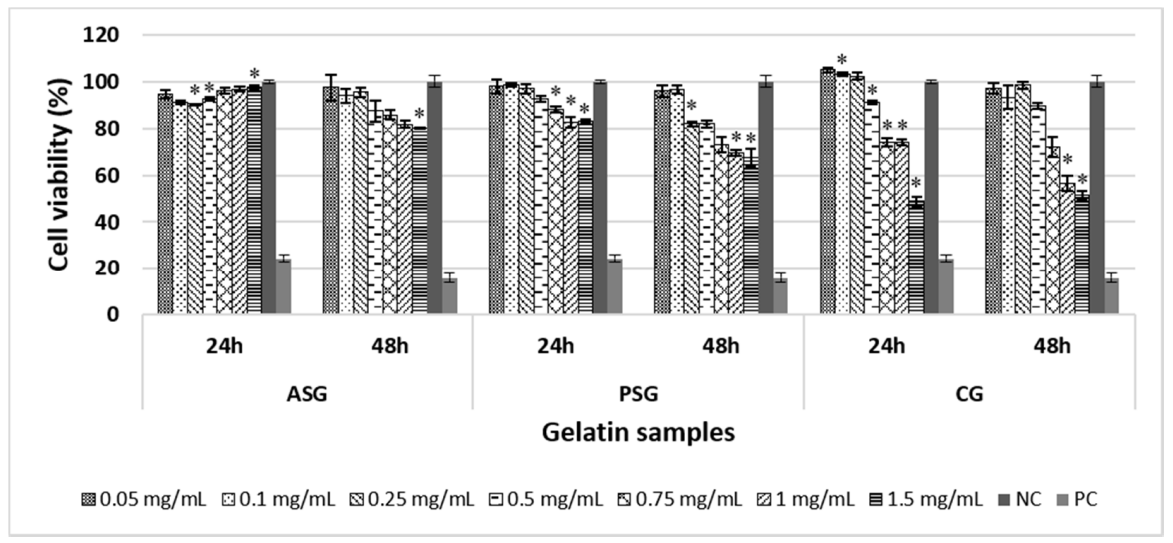

Figure 4. Cell viability of HaCaT cells exposed to increasing concentrations of ASG, PSG, and CG samples for 24 and $48 \mathrm{~h}$, as evaluated by MTT assay. The negative control (NC) was represented by untreated cells and the positive control (PC) was represented by $100 \mu \mathrm{M} \mathrm{H}_{2} \mathrm{O}_{2}$. All samples were normalized to the NC considered to be $100 \%$ viable. Data were presented as mean \pm SD $(n=3)$. $* p<0.05$ compared to the NC.

Previous studies have reported no cytotoxic effects of collagen/gelatin obtained from different marine sources on various cell lines. For example, collagen from codfish skin did not affect lung fibroblast metabolism at concentrations ranging between 0.01 and $0.05 \mathrm{mg} / \mathrm{mL}$, but exhibited cytotoxic activity at concentrations higher than $0.1 \mathrm{mg} / \mathrm{mL}$ [41]. Collagen obtained from the starfish Asterias amurensis also promoted growth and viability of human dermal fibroblasts at concentrations ranging between 0.01 and $1 \mathrm{mg} / \mathrm{mL}$ [42], whereas squid gelatin peptides $(0.025-0.1 \mathrm{mg} / \mathrm{mL})$ exhibited a dose-dependent increase of cell viability in oxidation-induced human lung fibroblasts [43].

\subsubsection{Morphological Examination}

Live/dead staining was used to evaluate the cell morphology and viability after the treatment with marine gelatin samples. Thus, HaCaT cells maintained their viability after $48 \mathrm{~h}$ of cultivation in the presence of marine and commercial gelatins, while few dead cells could be observed (Figure 5).
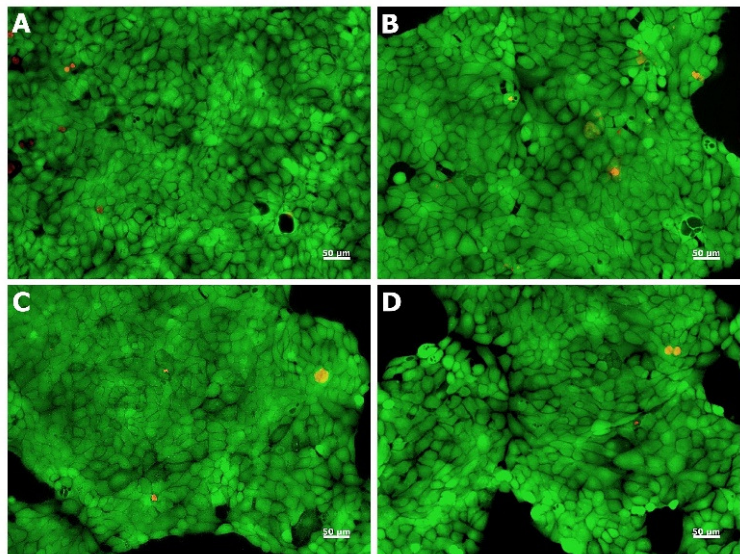

Figure 5. Live/dead staining with calcein-AM (green) and ethidium homodimer-1 (red) of HaCaT cells untreated control; (A) and treated with ASG (B), PSG (C), and CG (D) at the concentration of $0.25 \mathrm{mg} / \mathrm{mL}$. 
Furthermore, cells treated with marine and commercial gelatins showed no significant morphological changes, maintaining their normal phenotype when compared to that of the untreated cells. In addition, quantitative analysis of cell density performed with ImageJ software showed that more than $99 \%$ of cells were viable for all samples. ASG, PSG, and CG promoted growth and viability of human keratinocytes, results which correlated well with those obtained by the quantitative MTT assay.

\subsection{Biological Properties of Marine Gelatins}

\subsubsection{Cell Adhesion Capacity}

The adhesion of HaCaT cells on gelatin coatings was evaluated using phalloidin TRITC staining, which highlighted the actin filaments. The distribution of actin revealed the morphological changes at the cytoskeleton level in HaCaT cells (Figure 6).
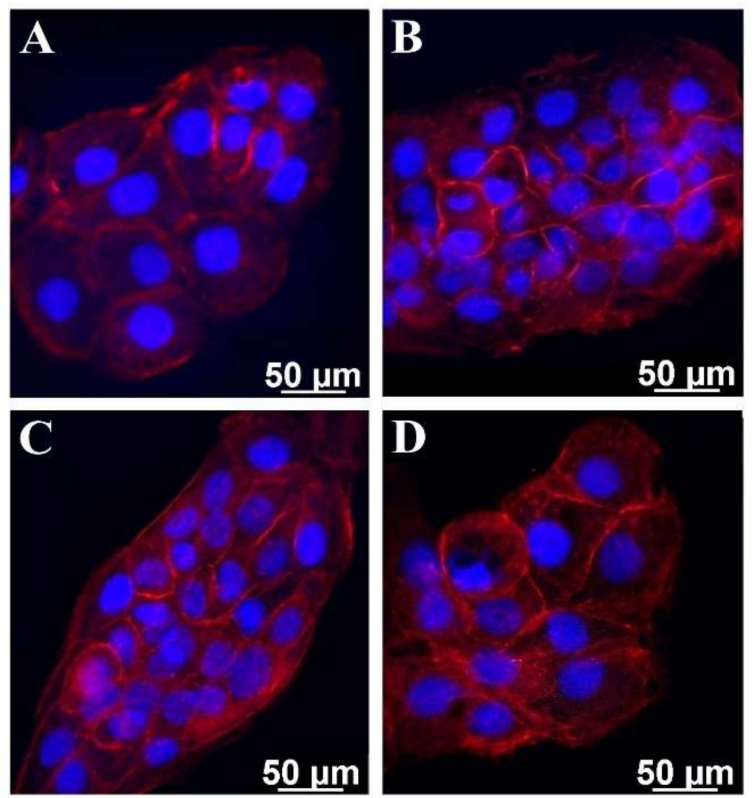

Figure 6. Distribution of actin filaments in $\mathrm{HaCaT}$ cells, assessed by fluorescence microscopy. HaCaT cells adhered to plastic (A) and to $0.25 \mathrm{mg} / \mathrm{mL}$ ASG (B), PSG (C), and CG coatings (D). Cells were stained for actin (red) and nuclei (blue).

In the control, cells exhibited a polygonal-shaped morphology typical of HaCaT cells, with actin filaments assembled into large radial bundles (Figure 6A). The cells cultivated on ASG- and PSG-coated coverslips presented a different actin distribution, with smaller filaments which were visualized close to the nucleus (Figure 6B,C). The cells that adhered to the CG coating presented morphological features similar to the control (Figure $6 \mathrm{~A}, \mathrm{D}$ ).

\subsubsection{Irritant Potential}

According to the Organization for Economic Cooperation and Development (OECD) guidelines for testing of chemicals, a substance is considered to be an irritant if it has the ability to decrease cell viability below the defined threshold of $50 \%$, when compared to the negative control (untreated cells). In our study, marine gelatin samples exhibited cell viability values higher than $50 \%$ at all tested concentrations, with values ranging between $73.33 \%$ and $108.33 \%$ and, therefore, can be considered non-irritants for skin. These results were also correlated with the low release of IL- 6 and IL- $1 \alpha$ proinflammatory cytokines as measured by ELISA assay. These interleukins are active and pleiotropic inflammatory cytokines that play a key role in the inflammatory process [44,45]. IL-1 $\alpha$ is a known endpoint to predict skin irritation and the concentration of IL-1 $\alpha$ released by keratinocytes in culture 
medium has been reported to increase after exposure to different irritants [46]. In our study, the cytokine content, expressed as pg/mL, varied with the sample concentration (Tables 2 and 3). Thus, in the case of ASG, the IL-1 $\alpha$ content varied from 1.39 to 6.72, whereas slightly higher values were observed for PSG (Table 2). For the CG sample, the concentration of IL-1 $\alpha$ was similar to that of the negative control, ranging between 0.37 and 1.06 . However, all these values were significantly lower than that of $0.1 \%$ SDS (40.93) used as positive control (Table 2).

Table 2. IL- $1 \alpha$ secretion levels expressed as $\mathrm{pg} / \mathrm{mL}$ in the culture medium of HaCaT keratinocytes treated with increasing concentrations of marine gelatin samples.

\begin{tabular}{|c|c|c|c|c|c|}
\hline \multirow{2}{*}{ Sample } & & \multicolumn{4}{|c|}{ Tested Concentrations } \\
\hline & & $0.1 \mathrm{mg} / \mathrm{mL}$ & $0.25 \mathrm{mg} / \mathrm{mL}$ & $0.5 \mathrm{mg} / \mathrm{mL}$ & $0.75 \mathrm{mg} / \mathrm{mL}$ \\
\hline ASG & & $1.39 \pm 0.27 *$ & $1.10 \pm 0.20 *$ & $3.40 \pm 0.55 *$ & $6.72 \pm 1.27$ * \\
\hline PSG & & $1.90 \pm 0.87^{*}$ & $2.82 \pm 0.94$ * & $5.85 \pm 1.83$ * & $7.35 \pm 1.00$ * \\
\hline CG & & $0.37 \pm 0.11$ * & $0.61 \pm 0.18 *$ & $0.77 \pm 0.21 *$ & $1.06 \pm 0.13$ * \\
\hline $\mathrm{NC}$ & $0.34 \pm 0.07 *$ & & & & \\
\hline PC & $40.93 \pm 4.02$ & & & & \\
\hline
\end{tabular}

NC- - negative control (untreated cells), PC-positive control (SDS 0.1\%). Values are expressed as mean $\pm \mathrm{SD}(n=3)$. ${ }^{*} p<0.05$ compared to PC.

The levels of IL-6 increased from 54.08 at the concentration of $0.1 \mathrm{mg} / \mathrm{mL}$ to 279.65 at the concentration of $0.75 \mathrm{mg} / \mathrm{mL}$ for ASG, and ranged between 92.67 and 384.02 for PSG (Table 3). Although the concentration of IL-6 released in culture medium was higher for PSG compared to ASG, all values were significantly lower compared to the positive control (1094.09). For the CG sample, the IL-6 content was slightly higher than that of the negative control, ranging between 30.49 and 98.52 (Table 3). For TNF- $\alpha$, no evidence of the release of this cytokine was detected in the cell culture medium after the treatment with gelatin samples for $18 \mathrm{~h}$. Similar results were reported by Alves et al. [47] in the case of human keratinocyte treatment with codfish skin collagen, where no release of IL-6 and IL-18 was detected in the culture medium, highlighting the non-irritant effect and cosmetic potential of marine collagen.

Table 3. IL-6 secretion levels expressed as $\mathrm{pg} / \mathrm{mL}$ in the culture medium of HaCaT keratinocytes treated with increasing concentrations of marine gelatin samples.

\begin{tabular}{|c|c|c|c|c|c|}
\hline \multirow{2}{*}{ Sample } & & \multicolumn{4}{|c|}{ Tested Concentrations } \\
\hline & & $0.1 \mathrm{mg} / \mathrm{mL}$ & $0.25 \mathrm{mg} / \mathrm{mL}$ & $0.5 \mathrm{mg} / \mathrm{mL}$ & $0.75 \mathrm{mg} / \mathrm{mL}$ \\
\hline ASG & & $54.08 \pm 1.49 *$ & $\begin{array}{c}162.81 \pm 3.03 \\
*\end{array}$ & $\begin{array}{c}244.24 \pm \\
19.70\end{array}$ & $\begin{array}{c}279.65 \pm \\
41.15^{*}\end{array}$ \\
\hline PSG & & $92.67 \pm 7.55$ * & $\begin{array}{c}196.44 \pm 6.79 \\
*\end{array}$ & $\begin{array}{c}311.89 \pm \\
16.10^{*}\end{array}$ & $\begin{array}{c}384.02 \pm \\
15.64\end{array}$ \\
\hline CG & & $46.46 \pm 3.10 *$ & $30.49 \pm 1.59 *$ & $98.52 \pm 1.78$ * & $42.53 \pm 4.65^{*}$ \\
\hline $\mathrm{NC}$ & $6.45 \pm 2.30 *$ & & & & \\
\hline PC & $1094.88 \pm 188.96$ & & & & \\
\hline
\end{tabular}

\section{Experimental Section}

\subsection{Raw Materials}

Marine snails were collected in August 2018 from the Romanian seacoast of the Black Sea between the 2 Mai and Vama Veche areas. The samples were washed with cold distilled water and stored at $-20{ }^{\circ} \mathrm{C}$ until use. CG from pig skin and other chemicals were purchased from Sigma-Aldrich (Saint Louis, MO, USA) unless otherwise specified. 


\subsection{Gelatin Extraction}

Snail soft tissue was removed from the hard shell, washed with distilled water for $30 \mathrm{~min}$, and cut into small pieces (2-5 mm) using scissors. In order to remove noncollagenous proteins, the cleaned tissue was pretreated with $0.5 \mathrm{M} \mathrm{NaOH}$ solution in a ratio of 1:10 $(w / v)$ at room temperature for $24 \mathrm{~h}$. After centrifugation at $5000 \mathrm{~g}$ for $30 \mathrm{~min}$, the obtained residue was washed with distilled water until neutral $\mathrm{pH}$ was achieved. Gelatin was extracted using acidic and enzymatic methods.

Acidic extraction was performed by gentle stirring of the pretreated tissue in $0.5 \mathrm{M}$ acetic acid solution $(1: 10, w / v)$ at room temperature for $24 \mathrm{~h}$. The sample was centrifuged at $8000 \mathrm{~g}$ for $40 \mathrm{~min}$ and heated at $60{ }^{\circ} \mathrm{C}$ in a shaking water bath (Witeg, Wertheim, Germany) for $20 \mathrm{~h}$. Then, the ASG solution was filtered to remove the insoluble material, dialyzed against distilled water, and freeze-dried at $-40^{\circ} \mathrm{C}$ for $48 \mathrm{~h}$.

For enzymatic extraction, the pretreated tissue was digested using pepsin from porcine gastric mucosa (2000 FIP-U/g, Carl Roth, Karlsruhe, Germany) in $0.5 \mathrm{M}$ acetic acid solution at a pepsin/dry tissue ratio of 1:10 (w/w) and continuously stirred at room temperature for $24 \mathrm{~h}$. The sample was centrifuged at $8000 \mathrm{~g}$ for $40 \mathrm{~min}$ and the resulting solution was subjected to thermal treatment at $98^{\circ} \mathrm{C}$ for $1 \mathrm{~min}$, in order to inactivate the enzyme. Then, the solution was heated at $60{ }^{\circ} \mathrm{C}$ in a shaking water bath for $20 \mathrm{~h}$. Finally, the PSG solution was filtered, dialyzed against distilled water, and freeze-dried at $-40{ }^{\circ} \mathrm{C}$ for $48 \mathrm{~h}$. The obtained gelatin powders were stored at $4{ }^{\circ} \mathrm{C}$ until use.

\subsection{Yield of Gelatin Extraction}

The yield of gelatin extraction was calculated based on wet weight of fresh tissue using the following formula:

Extraction yield $(\%)=$ Gelatin dried weight/Fresh tissuewet weight $\times 100$.

\subsection{Protein Content}

The total protein content was assessed using a bicinchoninic acid (BCA) protein assay kit, according to the manufacturer's instructions. The absorbance of the samples was read at $562 \mathrm{~nm}$, using an UV/VIS spectrophotometer (Jasco, V650, Tokyo, Japan). Bovine serum albumin (BSA) was used as standard.

\subsection{Hydroxyproline Content}

Hydroxyproline (Hyp) content of gelatin samples was determined according to the method of Edwards and O'Brien Jr [48], with several modifications. Briefly, gelatin samples (0.05 g) were hydrolyzed in $5 \mathrm{~mL}$ perchloric acid $70 \%$ at $120^{\circ} \mathrm{C}$ for $8 \mathrm{~h}$. The solutions were neutralized with 2.5 $\mathrm{N} \mathrm{NaOH}$ at $\mathrm{pH} 6$ and then an oxidant solution (a mixture of $1.41 \%$ chloramine $\mathrm{T}$ and acetate/citrate buffer, $\mathrm{pH}$ 6) was added. The mixtures were incubated at room temperature for $20 \mathrm{~min}$ and, finally, $26 \%$ perchloric acid and 10\% 4-(dimethylamino)benzaldehyde (DMAB) dissolved in $n$-propanol were added. The solutions were heated at $60{ }^{\circ} \mathrm{C}$ for $20 \mathrm{~min}$ and the absorbance was then read at $560 \mathrm{~nm}$ using an UV/VIS spectrophotometer (Jasco, V650, Tokyo, Japan). A hydroxyproline standard curve was prepared from serial dilutions in the range of concentrations $1-10 \mu \mathrm{g} / \mathrm{mL}$. The Hyp content was expressed as $\mathrm{g} / 100 \mathrm{~g}$ dry weight.

\subsection{Differential Scanning Calorimetry}

The melting temperature of gelatins was assessed by differential scanning calorimetry (DSC) using a Mettler Toledo (Greifensee, Switzerland) equipment. Freeze-dried samples (2-3 mg) were mixed with $10 \mu \mathrm{L}$ distilled water and incubated at temperatures ranging between 25 and $85^{\circ} \mathrm{C}$, with a heating rate of $2.5^{\circ} \mathrm{C} / \mathrm{min}$. 


\subsection{SDS-PAGE Analysis}

SDS-PAGE was conducted according to the method of Laemmli [49] with minor modifications. Samples were diluted in Laemmli buffer at a ratio of $1: 2(v / v)$, heated at $100{ }^{\circ} \mathrm{C}$ for $5 \mathrm{~min}$, and loaded on a 5\% stacking gel and a 7.5\% resolving gel. Then, they were migrated in a vertical gel unit (Biometra, Analytik Jena, Jena, Germany) at a constant current of $10 \mathrm{~mA}$ for $4 \mathrm{~h}$. After electrophoresis, the gels were stained using Roti Blue solution (Carl-Roth, Karlsruhe, Germany), destained in a solution of methanol/distilled water 1:3, and photographed. Commercial gelatin (CG) from pig skin was used as control and high molecular weight marker $(55-250 \mathrm{kDa})$ was migrated in the same conditions. The molecular weight of protein bands was determined using a logarithmic regression analysis by plotting the log of molecular weight versus relative mobility.

\subsection{FTIR Spectroscopy}

Gelatin samples were mixed with potassium bromide $(\mathrm{KBr})$ and ground into powder. FTIR spectra were performed in the range of wavelength between 4000 and $400 \mathrm{~cm}^{-1}$ with a resolution of $5 \mathrm{~cm}^{-1}$ using a Bruker Tensor 27 (Billerica, MA, USA) infrared spectrometer. A total of 50 scans was carried out for each sample.

\subsection{Scanning Electron Microscopy}

The structural morphology of gelatins was examined by SEM. Lyophilized samples were coated with a gold layer and visualized on TESCAN VEGA 3 LMH scanning microscope (Brno, Czech Republic) operated at $15 \mathrm{kV}$ in low vacuum mode.

\subsection{Cell Viability Evaluation}

In vitro experiments were performed on the spontaneously immortalized human keratinocyte cell line HaCaT purchased from AddexBio, San Diego, CA, USA. Cells were grown in RPMI 1640 culture medium (Biochrom, Berlin, Germany) supplemented with 10\% fetal bovine serum (FBS) and 1\% antibiotics (penicillin, streptomycin, and neomycin) at $37^{\circ} \mathrm{C}$ in a humidified atmosphere with $5 \% \mathrm{CO}_{2}$. In order to evaluate cell cytotoxicity, $\mathrm{HaCaT}$ cells were seeded in 96-well culture plates at a density of $5 \times 10^{4}$ cells $/ \mathrm{mL}$ and incubated for $24 \mathrm{~h}$ to allow cell attachment. After this period, fresh medium containing different concentrations of ASG, PSG, and CG $(0.05 ; 0.1 ; 0.25 ; 0.5 ; 0.75 ; 1$ and $1.5 \mathrm{mg} / \mathrm{mL})$ were added into each well and plates were incubated in standard conditions for 24 and $48 \mathrm{~h}$, respectively. Untreated cells and cells cultivated in the presence of $100 \mu \mathrm{M} \mathrm{H}_{2} \mathrm{O}_{2}$ served as negative and positive controls, respectively. Cell metabolic activity was measured using an MTT assay [47]. Briefly, MTT working solution $(0.25 \mathrm{mg} / \mathrm{mL}$ prepared in culture medium without FBS) was added to the cells and the plates were incubated at $37^{\circ} \mathrm{C}$ for $3 \mathrm{~h}$. The insoluble formazan crystals were dissolved using isopropanol and, after $15 \mathrm{~min}$ of incubation at room temperature with gentle stirring, the absorbance was read at $570 \mathrm{~nm}$ using a Mithras LB 940 microplate reader (Berthold Technologies, Bad Wildbad, Germany). The recorded value directly correlates to the number of metabolically active cells. The results of the MTT assay were calculated using the following equation: \%cell viability = sample absorbance/negative control absorbance $\times 100$. The negative control was considered $100 \%$ viable.

\subsection{Live/Dead Assay}

Cell morphology was assessed by fluorescence microscopy using the Live/Dead assay kit (Molecular Probes, Thermo Fisher Scientific, Eugene, OR, USA) according to the manufacturer's instructions. Briefly, after $48 \mathrm{~h}$ of cultivation in the presence of different gelatin samples, cells were stained with calcein-AM $(2 \mu \mathrm{M})$ and ethidium homodimer- $1(4 \mu \mathrm{M})$ at room temperature for $30 \mathrm{~min}$. Fluorescent images were acquired using an Axio Observer D1 microscope and analyzed using AxioVision 4.6 software (Carl Zeiss, Oberkochen, Germany). All images were processed using ImageJ 1.51 software (Bethesda, MD, USA) and quantitative analysis of cell density were performed counting 
calcein and ethidium homodimer-1 positive cells. The obtained values have been normalized to the control (100\% viability).

\subsection{Cell Adhesion Assay}

For cell adhesion assay, solutions containing $0.25 \mathrm{mg} / \mathrm{mL}$ of ASG, PSG and CG were added on coverslips previously inserted in 24-well plates and allowed to dry at room temperature, overnight. After evaporation, coatings were sterilized by UV irradiation for $3 \mathrm{~h}$. HaCaT cells were seeded at a density of $1 \times 10^{5}$ cells $/ \mathrm{mL}$ on coverslips coated with gelatin solution. Coverslips without gelatin coatings were used as control. After $24 \mathrm{~h}$ of incubation at $37{ }^{\circ} \mathrm{C}$ in a humidified atmosphere with $5 \% \mathrm{CO}_{2}$, the culture medium was discarded, and cells were washed with PBS and fixed with $4 \%$ formaldehyde. Cells were permeated with $0.1 \%$ Triton X-100 solution at room temperature for 10 min and stained with phalloidin TRITC $(50 \mu \mathrm{g} / \mathrm{mL})$ for $40 \mathrm{~min}$ and then with DAPI $(1 \mu \mathrm{g} / \mathrm{mL})$ for 10 min. Fluorescent images were acquired using an Axio Observer D1 microscope and analyzed using AxioVision 4.6 software (Carl Zeiss, Oberkochen, Germany). All images were processed using ImageJ 1.51 software (Bethesda, MD, USA).

\subsection{Irritant Potential Test}

In order to assess the irritant potential of gelatins, $\mathrm{HaCaT}$ cells were seeded in 24-well culture plates at a density of $1 \times 10^{5}$ cells/mL and cultivated in RPMI 1640 medium supplemented with $10 \%$ FBS. After $24 \mathrm{~h}$, gelatin samples $(0.1 ; 0.25 ; 0.5$, and $0.75 \mathrm{mg} / \mathrm{mL})$, negative control (cells grown in culture medium) and positive control (cells treated with $0.1 \%$ SDS) were added to the cells and incubated in standard conditions for $18 \mathrm{~h}$. The culture medium was collected and used for cytokine analysis. Levels of IL- 6 , IL- $1 \alpha$, and TNF- $\alpha$ proinflammatory cytokines were determined using commercial ELISA kits, according to the manufacturer's instructions (Invitrogen, Thermo Fisher Scientific, Vienna, Austria). The absorbance was recorded at $450 \mathrm{~nm}$ using a microplate reader Tecan Sunrise (Tecan, Grodig, Austria).

\subsection{Statistical Analysis}

All experiments were performed in triplicate, and the data are presented as mean \pm standard deviation (SD). Statistical analysis was performed using Student $t$-test. A value of $p<0.05$ was considered to be significant.

\section{Conclusions}

Gelatin was isolated for the first time from the marine snail $R$. venosa using acidic and enzymatic methods. The samples presented comparable values to commercial gelatin, in terms of protein, hydroxyproline content, and melting temperature. The structural features highlighted by FTIR spectra were slightly different for all tested gelatins. The electrophoretic profile showed a high degree of hydrolysis and peptides with low molecular weight for the enzymatic gelatin compared to acidic gelatin. Regarding the in vitro tests, gelatin obtained by chemical treatment showed a better cytocompatibility compared to the enzymatic extracted gelatin, with no signs of cytotoxicity and irritant potential. In addition, both marine gelatins promoted cell proliferation and cell-induced adhesion capacity when compared to mammalian gelatin. Overall, our results suggested that $R$. venosa marine snail could be a valuable alternative and safe source of gelatin, useful as an additive in biomedical and pharmaceutical skincare products.

Supplementary Materials: The following are available online at http://www.mdpi.com/1660-3397/17/10/589/s1, Figure S1: Thermal melting curves of ASG and PSG from R. venosa and CG from pig skin.

Author Contributions: A.G.-P., L.M.S., L.M. and T.N.-P. conceived and designed the study. A.G.-P., L.M., L.M.S., E.D.A., D.B. and C.M. performed the experiments. A.G.-P., L.M.S. and L.M. analyzed the data. A.G.-P., L.M.S., T.N.-P. and L.M. wrote the manuscript. All authors revised the manuscript and approved the final version. 
Funding: This work was supported by the Romanian Ministry of Research an Innovation, UEFISCDI, project No. PN-III-P1-1.2-PCCDI-2017-0701, grant no. 85PCCDI/2018. APC was funded by the Romanian Ministry of Research an Innovation, Institutional Performance Projects for Excellence Financing in RDI, grant No. 22PFE/2018.

Acknowledgments: The authors thank Raul-Augustin Mitran from "Ilie Murgulescu" Institute of Physical Chemistry, Bucharest, for melting temperature experiments.

Conflicts of Interest: The authors declare no conflict of interest.

\section{References}

1. Gorgieva, S.; Kokol, V. Collagen- vs. gelatin-based biomaterials and their biocompatibility: Review and perspectives. In Biomaterials Applications for Nanomedicine; Rosario, P., Ed.; InTech: Rijeka, Croatia, 2011; pp. 17-52. ISBN 978-953-307-661-4.

2. Duconseille, A.; Astruc, T.; Quintana, N.; Meersman, F.; Sante-Lhoutellier, V. Gelatin structure and composition linked to hard capsule dissolution: A review. Food Hydrocoll. 2015, 43, 360-376. [CrossRef]

3. Shoulders, M.D.; Raines, R.T. Collagen structure and stability. Ann. Rev. Biochem. 2009, 78, 929-958. [CrossRef] [PubMed]

4. See, S.F.; Ghassem, M.; Mamot, S.; Babji, A.S. Effect of different pretreatments on functional properties of African catfish (Clarias gariepinus) skin gelatin. Int. J. Food Sci. Technol. 2015, 52, 753-762. [CrossRef] [PubMed]

5. Nikkhah, M.; Akbari, M.; Paul, A.; Memic, A.; Dolatshahi-Pirouz, A.; Khademhosseini, A. Gelatin-based biomaterials for tissue engineering and stem cell bioengineering. In Biomaterials from Nature for Advanced Devices and Therapies; Neves, N.M., Reis, R.L., Eds.; John Wiley \& Sons, Inc.: Hoboken, NJ, USA, 2016; pp. 37-62. ISBN 9781119126218.

6. Karim, A.A.; Bhat, R. Fish gelatin: Properties, challenges, and prospects as an alternative to mammalian gelatins. Food Hydrocoll. 2009, 23, 563-576. [CrossRef]

7. Silva, T.; Moreira-Silva, J.; Marques, A.; Domingues, A.; Bayon, Y.; Reis, R. Marine origin collagens and its potential applications. Mar. Drugs 2014, 12, 5881-5901. [CrossRef]

8. Gómez-Guillén, M.C.; Giménez, B.; López-Caballero, M.A.; Montero, M.P. Functional and bioactive properties of collagen and gelatin from alternative sources: A review. Food Hydrocoll. 2011, 25, 1813-1827. [CrossRef]

9. Tziveleka, L.A.; Ioannou, E.; Tsiourvas, D.; Berillis, P.; Foufa, E.; Roussis, V. Collagen from the marine sponges Axinella cannabina and Suberites carnosus: Isolation and morphological, biochemical, and biophysical characterization. Mar. Drugs 2017, 15, 152. [CrossRef]

10. Silva, J.C.; Barros, A.A.; Aroso, I.M.; Fassini, D.; Silva, T.H.; Reis, R.L.; Duarte, A.R.C. Extraction of collagen/gelatin from the marine demosponge Chondrosia reniformis (Nardo, 1847) using water acidified with carbon dioxide-process optimization. Ind. Eng. Chem. Res. 2016, 55, 6922-6930. [CrossRef]

11. Barros, A.A.; Aroso, I.M.; Silva, T.H.; Mano, J.F.; Duarte, A.R.C.; Reis, R.L. Water and carbon dioxide: Green solvents for the extraction of collagen/gelatin from marine sponges. ACS Sustain. Chem. Eng. 2015, 3, $254-260$. [CrossRef]

12. Chancharern, P.; Laohakunjit, N.; Kerdchoechuen, O.; Thumthanaruk, B. Extraction of type A and type B gelatin from jellyfish (Lobonema smithii). Int. Food Res. J. 2016, 23, 419.

13. Cho, S.; Ahn, J.R.; Koo, J.S.; Kim, S.B. Physicochemical properties of gelatin from jellyfish Rhopilema hispidum. Fish. Aquat. Sci. 2014, 17, 299-304. [CrossRef]

14. Chan-Higuera, J.E.; Robles-Sánchez, R.M.; Burgos-Hernández, A.; Márquez-Ríos, E.; Velázquez-Contreras, C.A.; Ezquerra-Brauer, J.M. Squid by-product gelatines: Effect on oxidative stress biomarkers in healthy rats. Czech J. Food Sci. 2016, 34, 105-110. [CrossRef]

15. Uriarte-Montoya, M.H.; Santacruz-Ortega, H.; Cinco-Moroyoqui, F.J.; Rouzaud-Sández, O.; Plascencia-Jatomea, M.; Ezquerra-Brauer, J.M. Giant squid skin gelatin: Chemical composition and biophysical characterization. Food Res. Int. 2011, 44, 3243-3249. [CrossRef]

16. Nazeer, R.A.; Suganya, U.S. Porous scaffolds of gelatin from the marine gastropod Ficus variegate with commercial cross linkers for biomedical applications. Food Sci. Biotechnol. 2014, 23, 327-335. [CrossRef]

17. Zarai, Z.; Balti, R.; Mejdoub, H.; Gargouri, Y.; Sayari, A. Process for extracting gelatin from marine snail (Hexaplex trunculus): Chemical composition and functional properties. Process. Biochem. 2012, 47, 1779-1784. [CrossRef] 
18. Luo, F.; Xing, R.; Wang, X.; Peng, Q.; Li, P. Proximate composition, amino acid and fatty acid profiles of marine snail Rapana venosa meat, visceral mass and operculum. J. Sci. Food Agric. 2017, 97, 5361-5368. [CrossRef] [PubMed]

19. Badiu, D.L.; Balu, A.M.; Barbes, L.; Luque, R.; Nita, R.; Radu, M.; Rosoiu, N. Physico-chemical characterisation of lipids from Mytilus galloprovincialis (L.) and Rapana venosa and their healing properties on skin burns. Lipids 2008, 43, 829-849. [CrossRef]

20. Guven, K.C.; Yazic, Z.; Akinci, S.; Okus, E. Fatty acids and sterols of Rapana venosa (Valenciennes, 1846). J. Shellfish Res. 1999, 18, 601-604.

21. Zolotarev, V. The Black Sea ecosystem changes related to the introduction of new mollusc species. Mar. Ecol. 1996, 17, 227-236. [CrossRef]

22. Merdzhanova, A.; Panayotova, V.; Dobreva, D.A.; Stancheva, R.; Peycheva, K. Lipid composition of raw and cooked Rapana venosa from the Black Sea. Ovidius Univ. Ann. Chem. 2018, 29, 49-55. [CrossRef]

23. Badiu, D.L.; Luque, R.; Dumitrescu, E.; Craciun, A.; Dinca, D. Amino acids from Mytilus galloprovincialis (L.) and Rapana venosa molluscs accelerate skin wounds healing via enhancement of dermal and epidermal neoformation. Protein J. 2010, 29, 81-92. [CrossRef] [PubMed]

24. Luo, F.; Xing, R.; Wang, X.; Yang, H.; Li, P. Antioxidant activities of Rapana venosa meat and visceral mass during simulated gastrointestinal digestion and their membrane ultrafiltration fractions. Int. J. Food Sci. Technol. 2018, 53, 395-403. [CrossRef]

25. Schmidt, M.M.; Dornelles, R.C.P.; Mello, R.O.; Kubota, E.H.; Mazutti, M.A.; Kempka, A.P.; Demiate, I.M. Collagen extraction process. Int. Food Res. J. 2016, 23, 913-922.

26. Nalinanon, S.; Benjakul, S.; Visessanguan, W.; Kishimura, H. Improvement of gelatin extraction from bigeye snapper skin using pepsin-aided process in combination with protease inhibitor. Food Hydrocoll. 2008, 22, 615-622. [CrossRef]

27. Shyni, K.; Hema, G.S.; Ninan, G.; Mathew, S.; Joshy, C.G.; Lakshmanan, P.T. Isolation and characterization of gelatin from the skins of skipjack tuna (Katsuwonus pelamis), dog shark (Scoliodon sorrakowah), and rohu (Labeo rohita). Food Hydrocoll. 2014, 39, 68-76. [CrossRef]

28. Lin, C.C.; Chiou, T.K.; Sung, W.C. Characteristics of gelatin from giant grouper (Epinephelus lanceolatus) skin. Int. J. Food Prop. 2015, 18, 2339-2348. [CrossRef]

29. Jamilah, B.; Harvinder, K.G. Properties of gelatins from skins of fish—black tilapia (Oreochromis mossambicus) and red tilapia (Oreochromis nilotica). Food Chem. 2002, 77, 81-84. [CrossRef]

30. Milovanovic, I.; Hayes, M. Marine Gelatine from rest raw materials. Appl. Sci. 2018, 8, 2407. [CrossRef]

31. Kittiphattanabawon, P.; Benjakul, S.; Visessanguan, W.; Shahidi, F. Effect of extraction temperature on functional properties and antioxidative activities of gelatin from shark skin. Food Bioproc. Tech. 2012, 5, 2646-2654. [CrossRef]

32. Gudipati, V. Fish gelatin: A versatile ingredient for the food and pharmaceutical industries. In Marine Proteins and Peptides: Biological Activities and Applications; Kim, S., Wijesekara, I., Eds.; Wiley-Blackwell: Hoboken, NJ, USA, 2013; pp. 271-295. ISBN 9781118375082.

33. Vallejos, N.; González, G.; Troncoso, E.; Zúñiga, R.N. Acid and enzyme-aided collagen extraction from the byssus of Chilean mussels (Mytilus Chilensis): Effect of process parameters on extraction performance. Food Biophys. 2014, 9, 322-331. [CrossRef]

34. Grossman, S.; Bergman, M. Process for the Production of Gelatin from Fish Skins. U.S. Patent No 5093474A, 3 March 1992.

35. Dos Reis, R.L. Method to Obtain Collagen/Gelatin from Marine Sponges. WO Patent WO2015151030A1, 8 October 2015.

36. Alfaro, A.T.; Biluca, F.C.; Marquetti, C.; Tonial, I.B.; de Souza, N.E. African catfish (Clarias gariepinus) skin gelatin: Extraction optimization and physical-chemical properties. Food Res. Int. 2014, 65, 416-422. [CrossRef]

37. Kittiphattanabawon, P.; Benjakul, S.; Visessanguan, W.; Shahidi, F. Comparative study on characteristics of gelatin from the skins of brownbanded bamboo shark and blacktip shark as affected by extraction conditions. Food Hydrocoll. 2010, 24, 164-171. [CrossRef]

38. Sotelo, C.G.; Comesaña, M.B.; Ariza, P.R.; Pérez-Martín, R.I. Characterization of collagen from different discarded fish species of the West coast of the Iberian Peninsula. J. Aquat. Food Prod. T. 2016, 25, 388-399. [CrossRef] 
39. Blanco, M.; Vázquez, J.; Pérez-Martín, R.; Sotelo, C. Hydrolysates of fish skin collagen: An opportunity for valorizing fish industry byproducts. Mar. Drugs 2017, 15, 131. [CrossRef]

40. Cumming, M.H.; Hall, B.; Hofman, K. Isolation and characterization of major and minor collagens from hyaline cartilage of hoki (Macruronus novaezelandiae). Mar. Drugs 2019, 17, 223. [CrossRef]

41. Carvalho, A.; Marques, A.; Silva, T.; Reis, R. Evaluation of the potential of collagen from codfish skin as a biomaterial for biomedical applications. Mar. Drugs 2018, 16, 495. [CrossRef]

42. Lee, K.J.; Park, H.Y.; Kim, Y.K.; Park, J.I.; Yoon, H.D. Biochemical characterization of collagen from the starfish Asterias amurensis. J. Korean Soc. Appl. Biol. Chem. 2009, 52, 221-226. [CrossRef]

43. Mendis, E.; Rajapakse, N.; Byun, H.G.; Kim, S.K. Investigation of jumbo squid (Dosidicus gigas) skin gelatin peptides for their in vitro antioxidant effects. Life Sci. 2005, 77, 2166-2178. [CrossRef]

44. Di Paolo, N.C.; Shayakhmetov, D.M. Interleukin $1 \alpha$ and the inflammatory process. Nat. Immunol. 2016, 17, 906. [CrossRef]

45. Tanaka, T.; Narazaki, M.; Kishimoto, T. IL-6 in inflammation, immunity, and disease. Cold Spring Harb. Perspect. Biol. 2014, 6, a016295. [CrossRef]

46. Zhang, Q.; Dai, T.; Zhang, L.; Zhang, M.; Xiao, X.; Hu, H.; Huang, Y. Identification of potential biomarkers for predicting acute dermal irritation by proteomic analysis. J. Appl. Toxicol. 2011, 31, 762-772. [CrossRef] [PubMed]

47. Alves, A.; Marques, A.; Martins, E.; Silva, T.; Reis, R. Cosmetic potential of marine fish skin collagen. Cosmetics 2017, 4, 39. [CrossRef]

48. Edwards, C.A.; O’Brien, W.D., Jr. Modified assay for determination of hydroxyproline in a tissue hydrolyzate. Clin. Chim. Acta 1980, 104, 161-167. [CrossRef]

49. Laemmli, U.K. Cleavage of structural proteins during the assembly of the head of bacteriophage T4. Nature 1970, 227, 680. [CrossRef]

(C) 2019 by the authors. Licensee MDPI, Basel, Switzerland. This article is an open access article distributed under the terms and conditions of the Creative Commons Attribution (CC BY) license (http://creativecommons.org/licenses/by/4.0/). 